\title{
Below-Grade Planting Adversely Affects Survival and Growth of Tree Species from Five Different Families
}

\author{
Michael A. Arnold, Garry V. McDonald, Donita L. Bryan, Geoffrey C. Denny, W. Todd Watson, \\ and Leonardo Lombardini
}

\begin{abstract}
Adverse impacts of planting the root collar or main structural roots below grade on survival and growth were demonstrated for five species of container-grown trees from genetically diverse families. Adverse effects were demonstrated when root collars were located as little as $7.6 \mathrm{~cm}$ (3 in) below grade on all taxa tested, but severity of the responses varied among taxa. These responses were confirmed for both seed-propagated species, Fraxinus pennsylvanica Marsh. (green ash, family Oleaceae Hoffmansegg \& Link) and Platanus occidentalis L. (sycamore, family Platanaceae Dumort.) as well as cutting-propagated taxa, Lagerstroemia indica L. × Lagerstroemia fauriei Koehne. 'Basham's Party Pink' (crapemyrtle, family Lythraceae St.-Hilaire), Nerium oleander L. 'Cranberry Cooler' (oleander, family Apocynaceae Juss.), and Vitex agnus-castus L. 'LeCompte' (vitex, family Verbenaceae St.-Hilaire). In some cases, planting above grade by 7.6 $\mathrm{cm}$ (3 in) improved growth of plants over that of those planted either at or below grade. This effect was pronounced with sycamore and oleander.
\end{abstract}

Key Words. Apocynaceae; landscape installation; Lythraceae; Oleaceae; pine bark mulch; planting depth; Platanaceae; transplant establishment; tree planting; Verbenaceae.

Each year, millions of container-grown trees and shrubs are planted in landscapes worldwide. Many factors impact the initial establishment as well as the long-term development of these trees. Some factors such as circling roots in containers are related to the production system used to grow the tree (Watson and Himelick 1997; Ball 1999; Watson and Hewitt 2006). Others are the result of techniques used during the physical planting of the tree in the landscape (South 2005), whereas still others factors center around maintenance practices implemented after planting. However, in many cases, the successful establishment and long-term growth of a tree in the landscape is a result of interactions among multiple factors.

One of the practices receiving increased scrutiny during recent years is that of how deeply the root flare (also known as the root-to-shoot transition, root collar, or origin of the first of the primary structural roots) is placed in the planting hole (Watson and Hewitt 2006). In nature, trees often develop a spreading trunk flare, sometimes manifesting itself as a broad basal plate (Figure 1). However, trees planted in the landscape may be placed substantially below the surface resulting in a telephone pole-like base to the trunk. The fate of a deeply planted root system is often unknown, but in recent years, deeply planted root systems have become suspects in tree failures (Watson and Hewitt 2006). In general, trees are planted with the trunk flare deeper than would have occurred if the seedling naturally germinated in place, either by accident, as a result of practices used during production or transplanting, or by intent. Intentional below-grade planting of trees is attributed to one of four reasons. Trees, particularly some species of palms [family Arecaceae Schultz (Palmae)] are sometimes intentionally planted at different depths to achieve a uniform height (Broschat 1995). More commonly, trees are sometimes planted below grade in an attempt to reduce windthrow during establishment or to reduce the need for staking. In operational forestry plantings, small liners are sometimes intentionally planted deeper for improved access to moisture (South 2005); however, even then, there is controversy about whether it is a beneficial or detrimental practice. Finally, trees are sometimes planted with the root flare deeper than grade in an attempt to avoid root growth conflicts with components of the manmade infrastructures in the landscape (McPherson et al. 2001).

Most reports of tree responses to planting depth are based on anecdotal information. Little information on planting depth of trees is presently available in the scientific literature based on replicated, peer-reviewed studies (Browne and Tilt 1992; Broschat 1995; Gilman and Grabosky 2004; Arnold et al. 2005). Even less information is available on the interactions of cultural practices with planting depth (Gilman and 


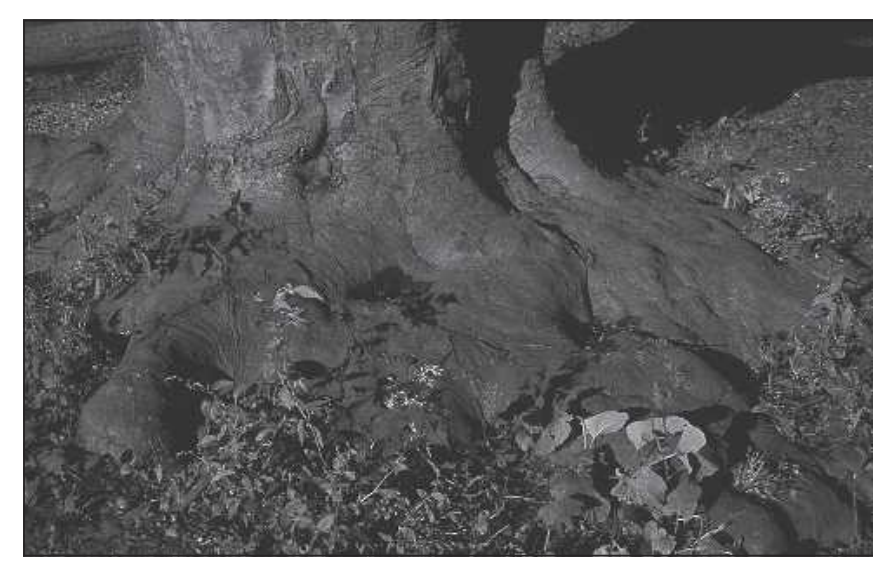

Figure 1. Basal plate on a naturally growing American Beech, Fagus grandifolia Ehrhart, with the root flare at or above the soil surface.

Grabosky, 2004; Arnold et al. 2005; Bryan et al. 2006). The objectives of this article were to investigate the responses of species from diverse families of trees and shrubs commonly cultivated in the southcentral United States to various planting depths.

\section{MATERIALS AND METHODS}

During Spring and Summer 2002, five species of trees and shrubs from diverse families were propagated and grown in an outdoor container nursery at the Texas A\&M University Horticultural Gardens in College Station, Texas, U.S. (latitude $30^{\circ} 60^{\prime} 44^{\prime} \mathrm{N}$ longitude $\left.96^{\circ} 31^{\prime} 22^{\prime} \mathrm{W}\right)$ in $9.3 \mathrm{~L}(2.42$ gal $)$ (\#3) black plastic containers (Lerio Corp., El Campo, TX) using a commercial pine bark-based substrate (3 milled pine bark:1 peat moss:1 coarse builders sand, by volume) amended with $6.8 \mathrm{~kg} / \mathrm{m}^{3}\left(12 \mathrm{lb} / \mathrm{yd}^{3}\right)$ of $18 \mathrm{~N}-3 \mathrm{P}-8.3 \mathrm{~K}$ controlled-release fertilizer (18 to 7-10; Scotts Corp., Marysville, $\mathrm{OH}), 3.4 \mathrm{~kg} / \mathrm{m}^{3}\left(6 \mathrm{lb} / \mathrm{yd}^{3}\right)$ of dolomite (Vulcan Materials Co., Tarrant, AL), $1.7 \mathrm{~kg} / \mathrm{m}^{3}$ (3 lb/yd $\left.\mathrm{d}^{3}\right)$ of gypsum (Standard Gypsum Corp., Fredericksburg, TX), and $0.68 \mathrm{~kg} / \mathrm{m}^{3}\left(1.5 \mathrm{lb} / \mathrm{yd}^{3}\right)$ of micromax micronutrients (Scotts Corp.).

Fraxinus pennsylvanica and Platanus occidentalis trees were grown from seed, whereas Lagerstroemia indica $\times \mathrm{La}$ gerstroemia fauriei 'Basham's Party Pink', Nerium oleander 'Cranberry Cooler', and Vitex agnus-castus 'LeCompte' were propagated from cuttings. Green ash and sycamore seeds were germinated in $38 \mathrm{~cm}(15.2$ in $) \times 53 \mathrm{~cm}(21.2 \mathrm{in}) \times 10 \mathrm{~cm}$ (4 in) black plastic flats (Kadon Corp., Dayton, $\mathrm{OH}$ ) containing moistened substrate. Crapemyrtle, oleander, and vitex cuttings were approximately $15 \mathrm{~cm}$ (6 in) long. The basal 6.4 $\mathrm{cm}$ (2.56 in) were placed in the substrate during rooting on a mist bench. Propagules were transplanted to the $9.3 \mathrm{~L}(2.42$ gal) (\#3) plastic containers after rooting for cuttings (4 to 6 weeks after sticking) and when the first true leaves emerged on seedlings ( 2 to 3 weeks after sowing). The same planting depth present for seedlings and cuttings during the propagation stage was maintained during nursery production to ensure that when plants were transplanted to the field site, the root collar, or in the case of cuttings, the original sticking depth, was placed at the desired depth in the soil profile. Irrigation water for the nursery was injected with concentrated sulfuric acid (Scholle Corp., Northlake, IL) to maintain water $\mathrm{pH}$ at 6.5 and with a $24 \mathrm{~N}-3.5 \mathrm{P}-13.2 \mathrm{~K}$ (24 to $8-16$, $7.19 \%$ ammonium nitrate, $7.21 \%$ urea, and $9.60 \%$ nitrate; Scotts Corp.) water-soluble fertilizer to yield a concentration of $50 \mathrm{mg} / \mathrm{L}^{1}(50 \mathrm{ppm}) \mathrm{N}$. Trees were staked and trained to a central leader during production.

In May 2003, all five species were transplanted to a field site in College Station, Texas, by placing the root collars for seedlings, or original sticking depth for cuttings, $7.6 \mathrm{~cm}$ (3 in) below grade, at grade, or $7.6 \mathrm{~cm}$ ( 3 in) above grade. Field plots contained a Boonville Series, Boonville fine sandy loam, fine, montmorillic thermic ruptic-vertic albaqualfs $(\mathrm{pH}$ 9.1 , bulk density $1.51 \mathrm{~g} / \mathrm{cm}^{3}, 61 \%$ sand, $11 \%$ clay, $28 \%$ silt) underlain at a 15.2 to $30.5 \mathrm{~cm}$ (6 to 12 in) depth with a hard clay pan. To ensure uniformity of disturbed soil volume within the planting holes, the holes were dug to accommodate the deepest planting depth possible (from the root collar to the bottom of the rootball plus $7.6 \mathrm{~cm}$ [3 in]) using a $45.7 \mathrm{~cm}$ (18.28 in) diameter auger mounted on a Dingo compact utility loader (The Toro Co., Bloomington, MN). This also ensured that the clay pan was punctured to the same depth in all holes. Sides of the holes were scarred to avoid glazing and the backfill tamped firmly to achieve the desired planting depths. Final planting depths placed the root collars $7.2 \mathrm{~cm}$ ( 3 in) below grade, at grade, or $7.2 \mathrm{~cm}$ (3 in) above grade. The excised native soil was used as backfill during planting.

No mulch was used, weeds were controlled by hand, and irrigation was provided using a commercial drip tape (TTape; T-Systems International Inc., San Diego, CA). Trees were irrigated daily during the first 4 weeks and thereafter when soil moisture reached $-15 \mathrm{kPa}$ ( -15 centibars) as indicated by tensiometers (Model 2725 JetFill Tensiometers; Soil Moisture Equipment Corp., Santa Barbara, CA).

The various taxa were arranged in a completely random factorial design of five taxa by three planting depths with six replicates of each taxa $\times$ planting depth combination. Tree height, trunk diameter, cross-sectional trunk area at $15 \mathrm{~cm}(6$ in) above the soil surface, and shrub height, canopy spread, and cross-sectional trunk area were determined for three growing seasons. For trees/shrubs with multiple trunks, crosssectional areas were calculated by totaling the calculated area for each stem using individual stem diameters. A canopy index (height $\times$ spread parallel to the row $\times$ spread perpendicular to the row) was also calculated as a volumetric estimate of the canopy size for the oleander, which remained more shrub-like in habit. Growth rates after transplant, adjusted for initial size, were calculated for height, trunk diam- 
Table 1. Three-year survival and growth increment of five taxa grown for 3 years in a field site in College Station, Texas, after transplant from $9.3 \mathrm{~L}(\# 3)$ black plastic containers.

\begin{tabular}{|c|c|c|c|c|c|}
\hline $\operatorname{Taxa}^{\mathrm{z}}$ & Planting depth ${ }^{\mathrm{y}}$ & $\begin{array}{l}\text { Survival } \\
\text { (no. out of } 6 \text { ) }\end{array}$ & $\begin{array}{l}\text { Height } \\
(\mathrm{cm})\end{array}$ & $\begin{array}{l}\text { Cross-sectional } \\
\text { area }\left(\mathrm{cm}^{2}\right)\end{array}$ & $\begin{array}{l}\text { Trunk diameter } \\
(\mathrm{mm})\end{array}$ \\
\hline \multirow[t]{3}{*}{ Lagerstroemia } & Below grade & 4 & $136 \pm 26^{x}$ & $3.9 \pm 2.6$ & $19.4 \pm 4.5$ \\
\hline & At grade & 6 & $185 \pm 21$ & $10.3 \pm 2.2$ & $22.8 \pm 3.7$ \\
\hline & Above grade & 6 & $176 \pm 21$ & $12.9 \pm 2.2$ & $25.7 \pm 3.7$ \\
\hline \multirow[t]{3}{*}{ Fraxinus } & Below grade & 3 & $138 \pm 30$ & $2.6 \pm 3.2$ & $17.4 \pm 5.2$ \\
\hline & At grade & 6 & $170 \pm 21$ & $4.9 \pm 2.2$ & $24.8 \pm 3.7$ \\
\hline & Above grade & 6 & $194 \pm 21$ & $4.2 \pm 2.2$ & $22.9 \pm 3.7$ \\
\hline \multirow[t]{3}{*}{ Nerium } & Below grade & 4 & $98 \pm 26$ & $3.1 \pm 2.8$ & $12.1 \pm 4.5$ \\
\hline & At grade & 6 & $121 \pm 21$ & $6.8 \pm 2.2$ & $21.2 \pm 3.7$ \\
\hline & Above grade & 6 & $145 \pm 21$ & $13.2 \pm 2.2$ & $18.4 \pm 3.7$ \\
\hline \multirow[t]{3}{*}{ Platanus } & Below grade & 3 & $212 \pm 26$ & $6.3 \pm 2.8$ & $26.6 \pm 4.5$ \\
\hline & At grade & 5 & $183 \pm 23$ & $6.0 \pm 2.5$ & $25.8 \pm 4.0$ \\
\hline & Above grade & 6 & $257 \pm 23$ & $13.6 \pm 2.5$ & $40.5 \pm 4.0$ \\
\hline \multirow[t]{3}{*}{ Vitex } & Below grade & 6 & $135 \pm 21$ & $7.8 \pm 2.2$ & $17.6 \pm 3.7$ \\
\hline & At grade & 6 & $152 \pm 21$ & $11.4 \pm 2.2$ & $23.6 \pm 3.7$ \\
\hline & Above grade & 6 & $150 \pm 21$ & $12.0 \pm 2.2$ & $25.6 \pm 3.7$ \\
\hline
\end{tabular}

${ }^{7}$ Five taxa included Lagerstroemia indica $\times$ Lagerstroemia fauriei 'Basham's Party Pink', Fraxinus pensylvanica, Nerium oleander 'Cranberry Cooler', Platanus occidentalis, and Vitex agnus-castus 'LeCompte'.

${ }^{\mathrm{y}}$ Root collar placed at grade or $7.6 \mathrm{~cm}$ (3 in) above or below grade.

${ }^{\mathrm{x}}$ Values represent the means $( \pm$ standard errors) of six plants per taxa and planting depth combination.

eter, and cross-sectional areas for years 2 and 3. For instance, adjusted trunk diameter growth rate year 2 (in units of millimeters incremental diameter per millimeter starting diameter $)=[$ (trunk diameter year $2-$ trunk diameter year 1$) /$ trunk diameter year 1]. Data were analyzed using the fixed-effects general linear models procedures in the SAS System for Windows, Release 9.1 (SAS Institute, Inc., Cary, NC).

\section{RESULTS AND DISCUSSION}

Survival after 3 years was nearly $100 \%$ for all species when planted at or above grade; however, when planted below

Table 2. Analysis of variance effects significance for 3 year survival, height, total cross-sectional trunk area, and trunk diameter five taxa grown for 3 years in a field site in College Station, Texas, after transplant from $9.3 \mathrm{~L}$ (\#3) black plastic containers.

\begin{tabular}{lllll}
\hline & & & $\begin{array}{l}\text { Cross- } \\
\text { sectional }\end{array}$ & $\begin{array}{l}\text { Trunk } \\
\text { diameter }\end{array}$ \\
variance effects & Survival & Height & area & diame \\
\hline Taxa $^{\mathrm{z}}$ & $\mathrm{NS}^{\mathrm{x}}$ & $* * *$ & $*$ & $* *$ \\
Planting depth & y* & $*$ & $* * *$ & $*$ \\
Taxa $\times$ planting depth & NS & NS & NS & NS \\
\hline
\end{tabular}

${ }^{\mathrm{z}}$ Five taxa included Lagerstroemia indica $\mathrm{x}$ Lagerstroemia fauriei 'Basham's Party Pink', Fraxinus pensylvanica, Nerium oleander 'Cranberry Cooler', Platanus occidentalis, and Vitex agnus-castus 'LeCompte'.

${ }^{\mathrm{y}}$ Root collar placed at grade or $7.6 \mathrm{~cm}$ (3 in) above or below grade.

x*, **, ***, NS indicates statistical significance of the effect at $P \leq 0.05$, $P \leq 0.01, P \leq 0.001$, or not significant, respectively. grade, survival was reduced for all species except vitex (Tables 1 and 2). Planting above grade did not affect survival rates relative to those planted at grade, except for sycamore, which actually survived in higher numbers when planted above grade than at grade (Table 1). With the exception of sycamore, which was significantly taller when planted above grade than at grade, planting above grade yielded similar heights as planting at grade (Tables 1 and 2). Planting below grade reduced the height growth of all taxa but sycamores. Below-grade planting reduced cross-sectional trunk area and trunk diameter of all taxa except sycamore, which had a smaller cross-sectional area and trunk diameter both below and at grade compared with above-grade planting (Tables 1 and 2). Oleanders that survived 3 years increased little in

Table 3. Effect of planting depth on the plant index of Nerium oleander 'Cranberry Cooler' grown for 3 years in a College Station, Texas, field site after transplant from $9.3 \mathrm{~L}(\# 3)$ black plastic containers.

\begin{tabular}{lll}
\hline Planting depth & & Plant index $^{\mathrm{y}}$ \\
\hline Below grade & $\left(\mathrm{m}^{3}\right)$ & \\
At grade & $0.47 \mathrm{~b}^{\mathrm{x}}$ & \\
Above grade & $1.39 \mathrm{~b}$ & \\
\hline
\end{tabular}

${ }^{\mathrm{z}}$ Root collar $7.6 \mathrm{~cm}$ (3 in) below grade, at grade, or $7.6 \mathrm{~cm}$ (3 in) above grade. ${ }^{\mathrm{y}}$ Height $\times$ diameter within row $\times$ diameter between rows representing a volumetric estimate of the canopy.

${ }^{\mathrm{x}}$ Means followed by the same letter are not significantly different $(P \leq 0.05)$ using least squares means comparisons. Values represent the means of six plants per planting depth. 
Table 4. Main effect of planting depth on the adjusted relative growth of trunk cross-sectional area and trunk diameter of Fraxinus pensylvanica trees grown for 3 years in a field site in College Station, Texas, after transplant from $9.3 \mathrm{~L}$ (\#3) black plastic containers ${ }^{2}$.

\begin{tabular}{|c|c|c|c|}
\hline \multirow[b]{2}{*}{$\begin{array}{l}\text { Planting } \\
\text { depth }^{\mathrm{y}}\end{array}$} & \multicolumn{2}{|c|}{ Trunk cross-sectional area } & \multirow{2}{*}{$\begin{array}{l}\text { Trunk diameter } \\
\text { Year } 2 \\
\left(\mathrm{~mm} \mathrm{~mm} \mathrm{~mm}^{-2}\right)\end{array}$} \\
\hline & $\begin{array}{l}\text { Year } 2 \\
\left(\mathrm{~cm}^{2} \mathrm{~cm}^{-2}\right)\end{array}$ & $\begin{array}{l}\text { Year } 3 \\
\left(\mathrm{~cm}^{2} \mathrm{~cm}^{-2}\right)\end{array}$ & \\
\hline Below grade & $190 \mathrm{~b}^{\mathrm{x}}$ & $258 \mathrm{~b}$ & $-0.07 \mathrm{~b}$ \\
\hline At grade & $395 \mathrm{a}$ & $484 \mathrm{a}$ & $0.53 \mathrm{a}$ \\
\hline Above grade & $350 \mathrm{a}$ & $414 \mathrm{a}$ & $0.39 \mathrm{a}$ \\
\hline
\end{tabular}

${ }^{\mathrm{z}}$ Adjusted relative growth of trunk cross-sectional area and trunk diameter refers to the incremental growth during the year relative to the initial value of the parameter.

${ }^{y}$ Root collar $7.6 \mathrm{~cm}$ (3 in) below grade, at grade, or $7.6 \mathrm{~cm}$ (3 in) above grade. ${ }^{\mathrm{x}}$ Means followed by the same letter are not significantly different $(P \leq 0.05)$ using least squares means comparisons. Values represent the means of six plants per planting depth.

canopy volume if planted below grade, whereas those planted above grade nearly doubled the canopy volume of those planted at grade (Table 3). Adjusted growth rates based on initial size for a given year differed among species (data not presented) but differed among planting depth treatments only for the second and third years' growth for trunk crosssectional area and second-year trunk diameter growth for green ash (Table 4).

These data show similar patterns of responses as observed for $F$. pennsylvanica and Koelreuteria paniculata Laxmann in previous studies (Arnold et al. 2005), but also illustrate the wide magnitude of variation in species responses to planting depth and that the pattern of response varies depending on the measure of survival or growth process observed. Given the soil type and overall climatic conditions present in 6 years (two consecutive 3 year studies), growth and/or survival was reduced on all species tested when trees were planted as little as $7.6 \mathrm{~cm}$ ( 3 in) below grade. This is in contrast to the results of Gilman and Grabosky (2004) and some of the species tested by Browne and Tilt (1992), in which survival or growth of a few species did not appear to be impacted by planting below grade, in some cases with even deeper planting than was tested in this study. Part of these differential results might be explained by the shorter duration of Gilman and Grabosky's study (7 months). Differences in growth and survival in the current study were greatest after 3 years. Also, the differences might be the result of a substantially heavier soil on the Texas site than the sandy soils in Gilman and Grabosky's Florida site. The soil type was not reported for Browne and Tilt's work, which makes it difficult to identify if differences between the studies were soil-related or the result of species differences. Another issue is the size or age of the planting stock. Gilman and Grabosky's trees were much larger and presumably older at transplant than the trees used in the current study. Although their larger sized stock may be more representative of commercial street tree installations, the smaller sized container stock used here may be very representative of homeowner-planted trees from mass market garden centers or, in the case of oleander, representative of commercial shrub installations. These smaller sized container stock represents millions of trees and shrubs planted annually in the United States. Short-term preliminary studies with Quercus virginiana Mill. on four contrasting soil types indicated that heavier soils and poor internal drainage tend to accentuate adverse responses in water relations, photosynthetic gas exchange properties, and growth parameters to planting below grade (Bryan et al. 2005, 2006). Adverse responses to deep planting in those studies were less severe on better drained sandy soils.

\section{CONCLUSIONS}

Data presented in this article provide strong evidence for the adverse effects of even modest below-grade planting on container-grown species from five genetically diverse families. In addition, this study shows growth is adversely affected for both seed and cutting-propagated container-grown nursery stock. Additional work is needed to determine the effects of soil types, irrigation regimes, planting times, stock size, and other posttransplant cultural practices on remediation or accentuation of the severity of plant responses to deep planting. Likewise, the impacts of cultural practices during container nursery production on responses of trees to below-grade planting have not been documented.

Acknowledgments. This project was funded in part by the Texas Agricultural Experiment Station and grants from the Morton Arboretum, National Urban and Community Forestry Advisory Council, TREE Fund, J. Frank Schmidt Family

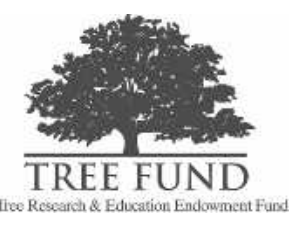
Charitable Foundation, and Texas Ornamental Enhancement Endowment. Mention of a trademark, proprietary product, or vendor does not constitute a guarantee or warranty of the product by the authors, the Texas A\&M University, or the Texas Agricultural Experiment Stationand does not imply its approval to the exclusion of other products and vendors that also may be suitable.

\section{LITERATURE CITED}

Arnold, M.A., G.V. McDonald, and D.L. Bryan. 2005. Planting depth and mulch thickness affect establishment of green ash and bougainvillea goldenraintree. Journal of Arboriculture 31:163-170.

Ball, J. 1999. Plant health care CEU series part VI: Tree planting - The foundation of PHC. Arborist News 8: 53-58.

Broschat, T. 1995. Planting depth affects survival, root growth, and nutrient content of transplanted pygmy date palms. HortScience 30:1031-1032. 
Browne, C., and K. Tilt. 1992. Effects of planting depth on three ornamental trees. Proc. Southern Nurserymen's Assoc. Res. Conf. 37:123-125.

Bryan, D.L., M.A. Arnold, G.V. McDonald, W.T. Watson, L. Lombardini, A.D. Cartmill, and G.C. Denny. 2006. Planting depth and cultural practices. Watson, G., Ed. Proc. of Trees and Planting: Getting the Roots Right Symposium, The Morton Arboretum, Lisle, IL, Nov. 10-11, 2005 http://www.mortonarb.org/research/roots/ (accessed 11/ 28/06) (in press).

Bryan, D.L., W.T. Watson, L. Lombardini, J.J. Sloan, A.D. Cartmill, G.C. Denny, and M.A. Arnold. 2005. Short-term responses of live oak to planting depth and soil amendments. HortScience 40:1079. (abstract).

Gilman, E.F., and J. Grabosky. 2004. Mulch and planting depth affect live oak (Quercus virginiana Mill.) establishment. Journal of Arboriculture 30:311-317.

McPherson, E., L.R. Costello, and D.W. Burger. 2001. Space wars: Can trees win the battle with infrastructure? Arborist News 10:21-24.

South, D.B. 2005. A review of the "pull-up" and "leavedown" methods of planting loblolly pine. Tree Planters' Notes 51:53-67.

Watson, G.W., and A. Hewitt. 2006. Getting the roots right. American Nurseryman 203:35-39.

Watson, G.W., and E.B. Himelick. 1997. Principles and Practice of Planting Trees and Shrubs. Intl. Soc. Arboric. Savoy, IL. 199 pp.

\section{Michael A. Arnold (corresponding author) \\ Professor}

Texas A\&M University

Department of Horticultural Sciences

M.S. 2133

College Station, TX 77843-2133, U.S.

ma-arnold@tamu.edu

\section{Garry V. McDonald}

PhD student and research/teaching assistant

Texas A\&M University

Department of Horticultural Sciences

M.S. 2133

College Station, TX 77843-2133, U.S.

\section{Donita L. Bryan}

PhD student

Texas A\&M University

Department of Horticultural Sciences

M.S. 2133

College Station, TX 77843-2133, U.S.
Geoffrey C. Denny

PhD student

Texas A\&M University

Department of Horticultural Sciences

M.S. 2133

College Station, TX 77843-2133, U.S.

W. Todd Watson

Assistant Professor

Department of Forest Science

Texas A\&M University

MS 2135

College Station, TX 77843-2135, U.S.

Leonardo Lombardini

Assistant Professor

Texas A\&M University

Department of Horticultural Sciences

M.S. 2133

College Station, TX 77843-2133, U.S.

Résumé. Les impacts adverses de la plantation du collet de racines ou des racines d'ancrage sous le niveau du sol en regard des taux de survie et de croissance a été démontré pour cinq espèces d'arbres produits en contenant et appartenant à diverses familles génétiques. Les effets adverses ont été démontrés lorsque les collets de racines ont été localisés aussi peu qu'à $7,6 \mathrm{~cm}$ sous le niveau du sol auprès de tous les sujets testés; mais la sévérité de la réponse variait selon l'espèce. Ces réponses ont été confirmées à la fois pour les sujets produits par semis - Fraxinus pennsylvanica Marsh. (famille des oléacées Hoffmansegg \& Link) et Platanus occidentalis L. (famille des platanacées Dumort) - que pour ceux produits par bouture - Lagerstroemia indica L. $\times$ Lagerstroemia fauriei Koehne. 'Basham's Party Pink' (famille des lythracées St.-Hilaire), Nerium oleander L. 'Cranberry Cooler' (famille des apocynacées Juss.) et Vitex agnus-castus L. 'LeCompte' (famille des verbenacées St.Hilaire). Dans certains cas, la plantation de 7,6 cm au-dessus du niveau du sol a permis d'améliorer la croissance des végétaux, et ce par rapport à ceux plantés au niveau ou sous le niveau du sol. Cet effet était prononcé avec le Platanus occidentalis et le Nerium oleander.

Resumen. Los impactos adversos en supervivencia y crecimiento de la descomposición del collar o raíces estructurales principales debajo del nivel del suelo, fueron demostrados para cinco especies de árboles crecidos en contenedor de familias genéticamente diversas. Los efectos adversos fueron comprobados cuando las descomposición del collar estuvo localizada a menos de $7.6 \mathrm{~cm}$. (3 pulg) debajo del suelo en todos los taxa probados, pero la severidad de las respuestas varió entre taxa. Estas respuestas fueron confirmadas para especies propagadas por semilla, Fraxinus pennsylvanica Marsh. (Fresno verde, familia Oleaceae Hoffmansegg \& Link) y Platanus occidentalis L. (sicomoro, familia Platanaceae Dumort.), así como también taxa propagados vegetativamente, Lagerstroemia indica $\mathrm{L}$. x Lagerstroemia fauriei Koehne. 'Basham's Party Pink' (crapemyrtle, familia Lythraceae St.-Hilaire), Nerium oleander L. 'Cran- 
berry Cooler' (oleander, familia Apocynaceae Juss.), y Vitex agnuscastus L. 'LeCompte' (vitex, familia Verbenaceae St.-Hilaire). En algunos casos, la plantación arriba de nivel a $7.6 \mathrm{~cm}$. (3 pulg) mejoró el crecimiento de las plantas sobre aquellas plantas a nivel o debajo del mismo. Este efecto fue pronunciado con sicomoro y oleander.

Zusammenfassung. An fünf Arten von Containerpflanzen aus genetisch unterschiedlichen Familien wurde die Überlebensrate und das Wachstum unter dem Einfluss von widrigen Umständen bei der Pflanzung des Wurzelkragens oder der Hauptwurzeln unter der Er- doberfläche demonstriert. Widrige Auswirkungen konnten demonstreit werden, wenn die Wurzelkragen aller getesteten Arten mehr als $7.6 \mathrm{~cm}$ unter der Oberfläche lagen, aber die Auswirkungen schwankten zwischen den Familien. Die Ergebnisse wurden bestätigt durch Sämlinge von Fraxinus penn., Platanus occ. und vegetativ vermehrte Lagerstroemia indica X Lagerstroemia fauriei, Nerium oleander und Vitex agnus-castus. In einigen Fällen verbesserte eine Pflanzung über der Tiefe von $7,6 \mathrm{~cm}$ das Wachstum gegenüber Pflanzungen bei $7,6 \mathrm{~cm}$ Tiefe oder darunter. Dieser Effekt konnte mit Platane und Oleander bestätigt werden. 